\title{
The Effect of Processing Trade on Employment: In Case of China
}

\author{
Yanjing Chen \\ School of Economics, Beijing Wuzi University, Beijing, China \\ Email: yanjing789@hotmail.com
}

Received October 26, 2011; revised November 19, 2011; accepted December 20, 2011

\begin{abstract}
In this paper, we use panel data from 2002 to 2008 on China's 31 provinces to analyze the effect of processing trade on regional employment. The results give evidence that processing trade has a significant and positive skill-bias effect on regional employment. Hereinto, processing import, including PIM and PSM import, especially the capital goods import by processing trade, is the root of the skill-bias effect of processing trade on employment. Net processing export is a driving to expand employment, including the skilled and the unskilled. But only PIM contributes to it.
\end{abstract}

Keywords: Processing Trade; Employment; Skill-Bias Effect; China

\section{Introduction}

With a reputation as a "world factory", China is a top supplier of manufacturing outsourcing for many global companies by processing trade. In 2008, processing trade value is 1053.49 billion USD, accounting for $41 \%$ of total trade value. And processing export value is 675.11 billion USD, accounting for $47 \%$ of total export value ${ }^{1}$. In line with literatures of processing trade, the study for effect of outward processing trade on labor market is highlighted on the outsourcing country, such as Feenstra and Hanson [1] and Ho, Wei and Wong [2]. Few pay attention to the effect on the host country. The current study tackles this area.

Impact of trade on employment includes both export and import. Theoretically, export growth should lead to more jobs via multiplier effects or via spillover effects. Most empirical studies give supports for the theatrical expectation, such as Leclair [3], Ruiz-Nápoles [4], Fu and Balasubramanyam [5], Feenstra and Hong [6], and still some researchers (e.g. Leichenko and Coulson [7]; Leichenko, [8]) suggest that rising capital intensity with export production leads to fewer jobs. Comparing with general trade, special of processing trade is that the demand for raw material, intermediate goods and capital goods is mostly met from outside. For example, according to a recent estimate by Koopman, Wang and Wei [9], the share of foreign content in China's exports is at about $50 \%$. Clearly, import caused by processing trade cannot be ignored. But the effect of import is mixed. Earlier studies suggest that imports can adversely affect domes-

${ }^{1}$ Calculated according to table 17-4 of China Statistical Yearbook 2009. tic employment. The recent researches are more cautious and specific, but have no consistent conclusion. For example, Conte and Vivarelli [10] suggests that Skill-enhancing technology import provides an absolute skillbias effect on the employment trends of skilled and unskilled workers witnessed in low and middle income countries. But based on panel data across countries, Mitra [11] examines the possible effect of the imported technology on labor absorption in the industrial sector. Findings tend to suggest a negative relationship between the two. In conclusion, the specific effect and merchandise of processing trade on employment of host country is complex.

In this paper, we use panel data from 2002 to 2008 on China's 31 provinces to analyze the effects of processing trade on employment. The results give evidence that processing trade has a significant and positive skill-bias effect on regional employment. Hereinto, processing import, including imports induced by processing or assembly imported materials (PIM) and processing or assembly supplied materials (PSM), especially the capital goods import by processing trade, is the root of the skill-bias effect of processing trade on employment. Net processing export is a driving to expand employment, including the skilled and the unskilled. But only PIM contributes to it.

This paper is organized as follows. Section 2 describes the processing trade in China. Section 3 discusses theoretical and empirical framework. Section 4 describes the dataset employed. The empirical results are discussed in Section 4. Section 5 concludes the paper.

\section{Processing Trade in China}

In China, the processing trade policy began in July 1978, 
when China State Council issued "Enforcement Measures of Outward Processing and Assemble Business". And in September 1979, China State Council formally issued "Measure for developing outward processing and Assemble and small and medium-sized compensation trade". From then on processing trade enjoy many preferential policies. For instance, import and export by processing export can do not be counted into total amount of country control and do not need to have the import or export license. Processing trade enterprises enjoy higher foreign exchange retention ratios. Although in recent years, Chinese government gradually gains ground this particular preference solely enjoyed by processing trade to all foreign trade types, the imported materials can be exempted from import duties is maintained till now.

Prompted by these particular preference policies, processing trade is boomed up in China. Figure 1 shows the change of processing export ratio to total export from 1985 to 2008. In Figure 1, processing export exceeds 50\% of total export since 1996, hits a high point at $57 \%$ in 1999 , and gradually declines back to $47 \%$ in 2008 . Figure 2 reports the change of processing export ratio to GDP from 1985 to 2008. In Figure 2, processing export ratio to GDP is 0.19 in 2006, hitting a high point in sample years.

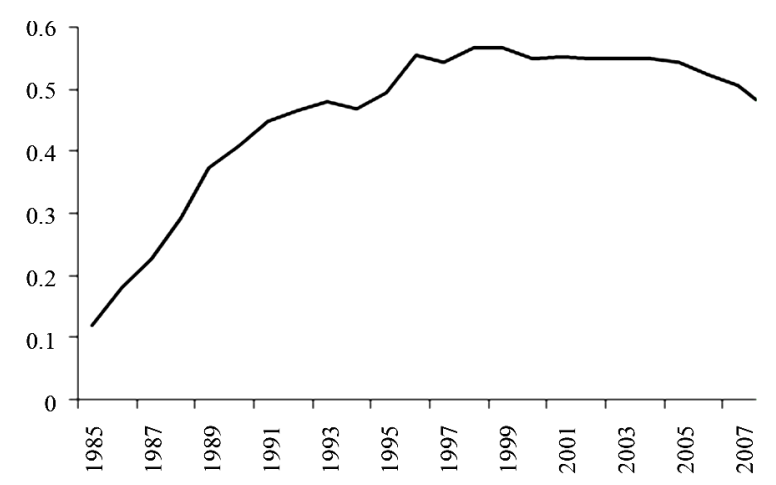

Figure 1. Processing Export Ratio to total export, 1985-2008 (in \%).

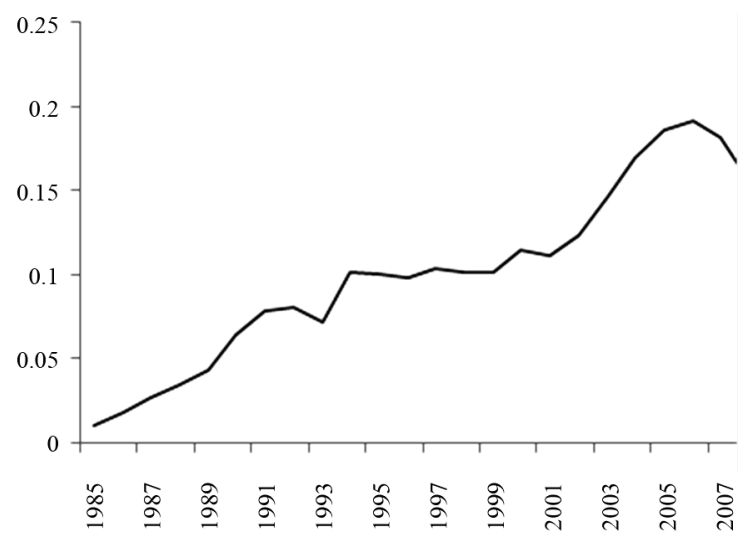

Figure 2. Processing Export Ratio to GDP, 1985-2008 (in \%).

\subsection{Structure Changes in Processing Trade}

In Figure 3, the contribution of processed exports from 2003 to 2008 was outstandingly large in machinery products, which includes sector machinery, electrical machinery, other transportation equipment and instruments. Besides, machinery contribution steadily maintains in sample years the situation that rises continuously. Manufactured product contribution maintains the situation that declines continuously. And the primary products contribution remains stably small at $2.1 \%$ around. So the diversification of China's processing trade is towards more technologically advanced products. But note that China does not master the entire production process or key process in these industries but has established its specialization in the labor intensive stages of production.

\subsection{Increased Local Content}

Since 1989, processing trade has been responsible for a growing part of China's trade surplus. The ratio of exports after processing to import for processing steadily increased, from 1.15 to 1.78 from 1989 to 2008 (Figure 4). This trend reflects the increasing local content of processed exports.

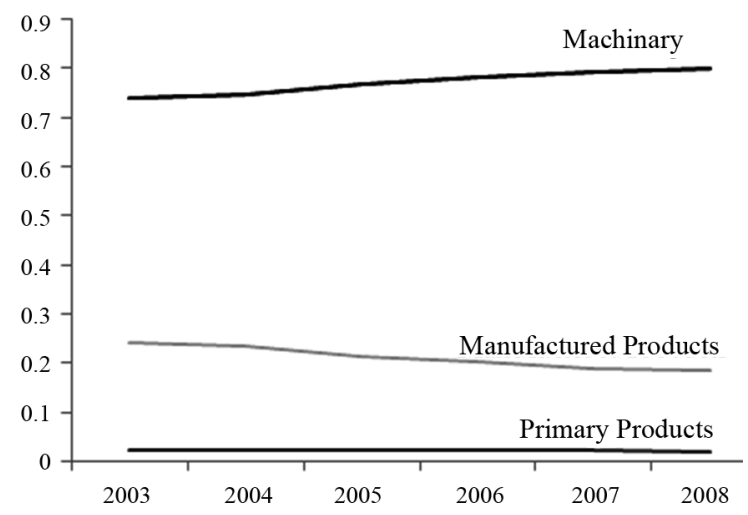

Figure 3. Share of Processed products in Total Processing Exports, 2003-2008 (in \%).

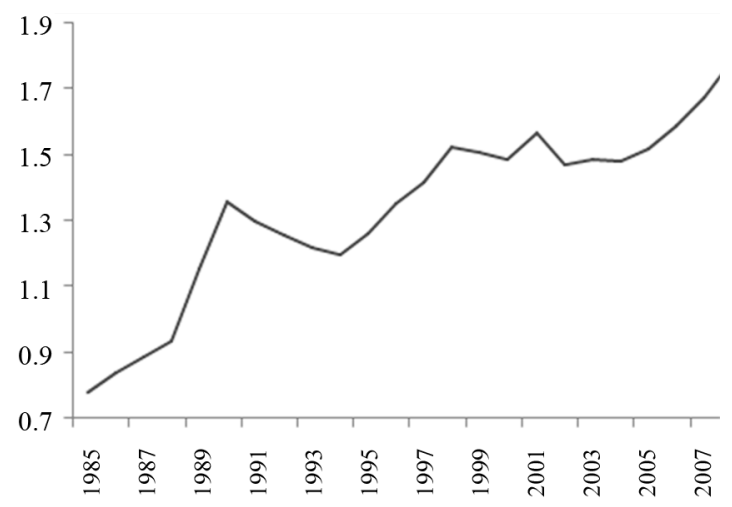

Figure 4. Exports/Imports Ratio of processing trade, 19852008 (in \%). 


\subsection{Dominated PIM Processing Trade}

In China There are two types of processing trade-PIM trade and PSM trade. According to "on processing trade statistics system" jointly enacted by the Ministry of Commerce and the National Bureau of statistics of China in 1994, PSM trade means foreign enterprises provide all or part of the raw materials, accessories, components, spare parts, packaging materials, etc., and if necessary, some equipment and technology. Domestic enterprises specialize in processing production for offset sales in accordance with the provisions of the contract, specifications, quality, style, etc; PIM trade refers to domestic producers import some or all of the raw materials, parts from the international market, process them into finished products and export. According to Figure 5, Obviously, PIM export is the dominated processing trade in China.

\section{Theoretical and Empirical Framework}

Here we adopt a Cobb-Douglas type function for the purpose of looking at labor demand. The model of the production function to be estimated is given according to Equation (1) below:

$$
Y_{i t}=A_{i t} K_{i t}^{\alpha} L_{i t}^{\beta}
$$

where $Y$ is output, $K$ is capital, $L$ is labor. A represents total factor productivity. $\alpha$ and $\beta$ represent the factor share coefficients. $i$ and $t$ denote provinces and year respectively.

Following Fu and Balasubramanyam [12], Assuming that firms are profit-maximizing, the marginal product of labor equals the wage $(w)$ and the marginal product of capital equals its user cost $(c)$. Eliminating capital from the Equation (1) by solving these equations, and get the following equation:

$$
Y_{i t}=A_{i t}\left(\frac{\alpha L_{i t}}{\beta} \cdot \frac{w_{i t}}{c}\right)^{\alpha} L_{i t}^{\beta}
$$

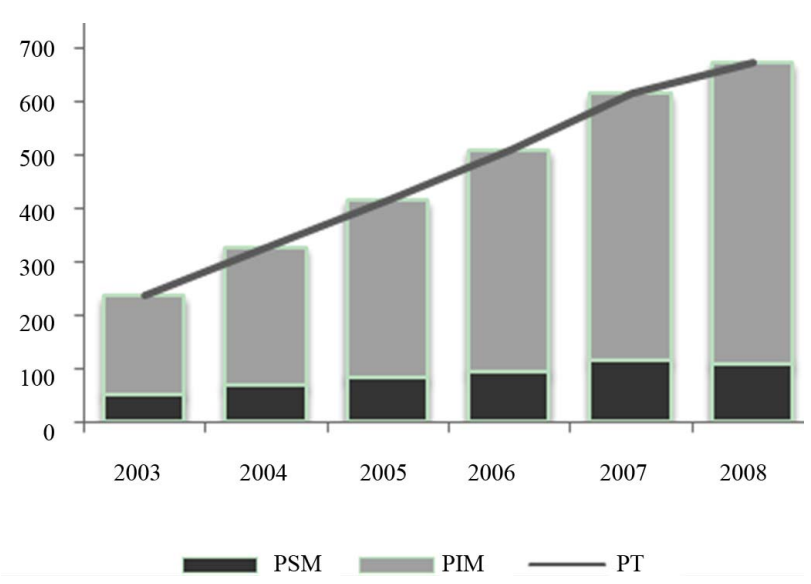

Figure 5. PSM and PIM Export, 2003-2008 (in billion US\$).
We extend the model by allowing for processing exports to influence labor demand. first, possible technology transfer via processing trade may promote technical efficiency of the production process due to pressures of competition in the international markets and knowledge spillovers from material and capital apparatus imports. Therefore, TFP may be hypothesized to vary with time in the following manner:

$$
A_{i t}=A_{0} e^{\eta_{0} t_{i}} P I_{i t}^{\eta_{1}}, \eta_{0}, \eta_{1}>0
$$

where $t$ is time trend, PI is import caused by processing trade, including materials and capital goods. Imported high-quality raw material and high-tech capital goods popularly used in processing trade reflect drastic international market competition, mean more likely knowledge spillovers, and mean higher import value at the same time.

By taking logarithms and rearranging the Equation (2), obtain the base labor demand equation as follows:

$$
\begin{aligned}
\ln \left(L_{i t}\right)= & \delta_{0}+\delta_{1} \ln \left(\frac{w_{i t}}{c}\right)+\delta_{2} \ln P I+\delta_{3} \ln Y_{i t} \\
& +\eta_{0} t_{i}+\varepsilon_{i t}
\end{aligned}
$$

When processing exports serve as a vent for surplus, export expansion may increase labor demand, just like general trade. Following Fu and Balasubramanyam [5], we decompose output $(Y)$ into real processing exports $(P E)$, other real output excluding processing export $(O O)$. Thus the labor demand equation which the processing trade is modeled to impact on efficiency is of the following form:

$$
\begin{aligned}
\ln \left(L_{i t}\right)= & \delta_{0}+\delta_{1} \ln \left(w_{i t} / c\right)+\delta_{2} \ln P I+\delta_{3} \ln P E_{i t} \\
& +\delta_{4} \ln O O_{i t}+\eta_{0} t_{i}+\varepsilon_{i t}
\end{aligned}
$$

With the assumption of immovable labor supply, Equation (5) is our basic specification for examining causality between processing trade and employment. Total number of regional employment (in logs), the number of technical personnel (in logs) and the number of nontechnical personnel (in logs) are independent variables respectively. The dependent variables are regional average wage, processing import to GPP ratio, processing export to GPP ratio, GPP subtracting processing export (in logs). And processing export value (in logs) is also used to control the total size.

\section{Data}

Original data of regional information on 31 provinces that make up Mainland China is mainly compiled from two series public publications of National Bureau of Statistics of China: China's Statistical Yearbook and China Labor Statistical Yearbook. The specific information includes nominal General Provincial Products (GPP) 2002- 
2008 in 100 million RMB Yuan, provincial consumer price index (CPI), nominal average wage in RMB Yuan, number of total employment in 10 thousands, number of technical personnel in person. GPP and average wage have been adjusted to reflect 2000 constant prices using provincial CPI. Prior to adjust processing exports, they are transformed into RMB Yuan using yearly average exchange rate.

The information of processing trade on 31 provinces is from General Administration of Customs of People's Republic of China. The specific information includes total processing export, PSM export, PIM export in USD, total processing import, capital goods import caused by processing import, PSM import and PIM import. Table 1 presents the summary statistics of our sample.

\section{Results and Discussion}

Given the analytical framework described in Section 3 we could test for impact of processing trade on regional employment. Until then, there are several potential econometric problems need to be clarified. First, the results of both Breusch-Pagan and Hausman tests prefer random effects model to simple OLS and fixed effects model. Therefore, random-effects analysis (RE) is employed, and time dummy is controlled at the same time. Second, the empirical analysis is based on data for China's 31 provinces and autonomous regions over the years 2002 to 2008. The small sample size necessarily calls for cautious analysis of the results. Although the robust variance estimator which could improve the overall estimate's small-sample properties is formally reported here, the result of standard variance estimator is totally consistent to the reported. Third, just as expected, proxies for processing export and processing import are highly corre-

Table 1. The summary statistics of variables.

\begin{tabular}{lccccc}
\hline \multicolumn{1}{c}{ Variable } & Obs. & Mean & S.D. & Min. & Max. \\
\hline Employment & 217 & 7.37 & 0.93 & 4.86 & 8.67 \\
The skilled employment & 217 & 13.6 & 0.87 & 10.49 & 14.69 \\
The unskilled employment & 217 & 16.52 & 0.94 & 14.04 & 17.85 \\
Processing export size & 217 & 21.55 & 5.00 & 0 & 28.14 \\
Gross processing export & 217 & 0.08 & 0.14 & 0 & 0.64 \\
Net processing export & 217 & 0.03 & 0.06 & -0.01 & 0.25 \\
Processing import & 217 & 0.05 & 0.09 & 0 & 0.44 \\
Capital goods imported & 217 & 0 & 0 & 0 & 0.01 \\
by PT & 217 & 9.78 & 0.38 & 9.12 & 10.92 \\
wage & 217 & 26.67 & 1 & 23.50 & 28.61 \\
Output excluding & 217 & 0.07 & 0.12 & 0 & 0.50 \\
processing export & 217 & 0.01 & 0.03 & 0 & 0.19 \\
PIM export & 217 & 0.03 & 0.05 & 0 & 0.24 \\
PSM export & 217 & 0 & 0.01 & -0.02 & 0.06 \\
Net PIM export & 217 & 0.04 & 0.07 & 0 & 0.32 \\
Net PSM export & 217 & 0.01 & 0.02 & 0 & 0.14 \\
PIM import & & & & & \\
PSM import & & & & & \\
\hline
\end{tabular}

Lated $^{2}$. In voiding of multicollinearity's happening, the proxies of processing import and export have to be tested dividedly. The results are reported in Table 2.

The empirical results of models with three different dependant variables-total employment (Model 1), the skilled (Model 2) and the unskilled employment (Model 3) are shown in 3 columns of Table 2 in turn. For each column, specifications 1) include gross processing export intensity, processing trade size, average wage and output excluding processing export as independent variables. Specifications 2) use net processing export and processing import instead of gross processing export. Specification 3) uses import of capital goods caused by processing export instead of processing import ahead.

First, just as expected, the empirical results of Model 1 and 3 are totally consistent in light of the fact that the unskilled employment is dominated in total employment. Second, I find the impacts of gross processing export on the skilled and the unskilled employment are both significantly positive, yet are obviously distinguished from the scale. The coefficients of gross processing export are 1.05 in Model 2, and 0.68 in Model 3 as shown in Table 2. For a more cautious assessment, gross processing export is divided into net processing export and processing import, respectively examined in Specification 2). The results show that the $1 \%$ increase in net processing export intensity leads to $1.01 \%$ increase in total regional employment, $1.14 \%$ in the skilled employment and $1.08 \%$ in the unskilled employment. And all of the coefficients are statistically significant in $1 \%$ confidence level. These findings support the "vent for surplus" theory, which is known to this phenomenon: When exports serve as a vent for surplus, export expansion may increase local labor demand and help for employment, applicative for processing trade. The "vent for surplus" effect does not place emphasis on the skilled employment. But the estimated result of the processing import contributes to explain the skill-bias effect. The coefficient of processing import is 0.98 , statistically significant only in Model 2 , in $1 \%$ confidence level, but insignificant in Model 3. This finding points out the skill-bias effect of processing trade on employment owes to processing import.

For robust results and more information, capital goods import caused by processing trade is tested in Specification 3). Just as expected, the coefficient of capital goods import caused by processing trade is 19.96 , statistically significant also only in Model 2 in 1\% confidence level. These results further proved that it is processing import, especially capital goods import, leads to the skilled-bias effect on employment. The explanation is relatively simple: on the one hand, capital goods need to be matched with technical worker, which promotes the relative demand for the skilled. Moreover, as stated in Section 2,

\footnotetext{
${ }^{2}$ The coefficients between processing export and opposite processing import are larger than 0.90 .
} 
the rapid expansion of China's processing trade was associated with the rapid export increase of more capital intensive goods with more technological sophistication. So more imports of high-tech processing industry further increases the relative demand for the skilled. This view is consistent with Tong and Zheng [13]; on the other hand, Lall and Albaladejo [14] suggests "Processing activity is increasingly organized as part of integrated production systems, particularly its high technology segments, though some domestic oriented industries are also being plugged into this system as they realize scale and learning economies and become globally competitive.” Therefore, expansion of processing import induces learning effect which prompts the demand of all local manufactures for the skilled labor.

I further test the effects of two disaggregated types of processing trade-PIM and PSM on regional employment using same regression and the result is reported in Table 3. The results are consistent with our benchmark test, and further provide important information.
In Table 3, the coefficients of PIM export are 0.77, 1, and 0.81 respectively, statistically significant in three models. The coefficient of PSM export is 1.14, statistically significant only in Model 2. The results suggest that PSM trade has a skill-bias effect on regional employment. This result is consistent with the style: comparing with PIM, the foreign party involves more deeply in PSM trade. Besides raw materials, foreign party not only supply technology and apparatus partly or wholly, but also specifies the quality, specification or design. Enterprises dealing in PSM trade lay more stress on product quality for meeting the demand of foreign partners who often are famous for their products' quality. More labor demand for the skilled is produced.

Further, in Table 3, the coefficients of net PIM export are positive, and significant in all models. Relatively, the coefficients of net PSM export are statistically insignificant. For PSM, foreign party supply absolutely most of necessaries of production, and the finished goods only could sell back to the foreign party. Processing fee is the

Table 2. Effects of processing trade on regional employment.

\begin{tabular}{|c|c|c|c|c|c|c|c|c|c|}
\hline \multirow{2}{*}{$\begin{array}{c}\text { Dependant Variable } \\
\text { Variable }\end{array}$} & \multicolumn{3}{|c|}{ Model 1 Total Employment } & \multicolumn{3}{|c|}{ Model 2 The Skilled Employment } & \multicolumn{3}{|c|}{ Model 3 The Unskilled Employment } \\
\hline & (1) & (2) & (3) & (1) & (2) & (3) & (1) & (2) & (3) \\
\hline Gross processing export & $\begin{array}{l}0.65^{*} \\
(4.8)\end{array}$ & & & $\begin{array}{l}1.05^{*} \\
(7.08)\end{array}$ & & & $\begin{array}{l}0.68^{*} \\
(4.57)\end{array}$ & & \\
\hline \multirow{2}{*}{ Net processing export } & & $1.01^{*}$ & $1.08^{*}$ & & $1.14^{*}$ & $1.26^{*}$ & & $1.08^{*}$ & $1.16^{*}$ \\
\hline & & (5.09) & $(4.94)$ & & (4.97) & $(5.81)$ & & $(4.94)$ & $(4.81)$ \\
\hline \multirow{2}{*}{ Processing import } & & 0.26 & & & $0.98^{*}$ & & & 0.24 & \\
\hline & & $(1.51)$ & & & $(4.41)$ & & & $(1.29)$ & \\
\hline \multirow{2}{*}{ Capital goods import } & & & 0.12 & & & $19.96^{*}$ & & & -0.81 \\
\hline & & & $(0.04)$ & & & $(5.07)$ & & & $(-0.27)$ \\
\hline \multirow{2}{*}{ Processing trade size } & 0.00 & 0.00 & 0.00 & 0.00 & 0.00 & 0.00 & 0.00 & 0.00 & 0.00 \\
\hline & $(-0.1)$ & $(-0.01)$ & $(0.06)$ & $(-0.57)$ & $(-0.48)$ & $(-0.28)$ & $(-0.12)$ & $(-0.02)$ & $(0.05)$ \\
\hline \multirow{2}{*}{ Average wage } & $-0.42^{*}$ & $-0.40^{*}$ & $-0.38^{*}$ & $-0.58^{*}$ & $-0.58^{*}$ & $-0.55^{*}$ & $-0.42^{*}$ & $-0.39^{*}$ & $-0.37^{*}$ \\
\hline & $(-6.17)$ & $(-5.88)$ & $(-5.83)$ & $(-6.5)$ & $(-6.42)$ & $(-6.03)$ & $(-5.88)$ & $(-5.53)$ & $(-5.52)$ \\
\hline \multirow{2}{*}{ Other Output } & $0.29^{*}$ & $0.28^{*}$ & $0.28^{*}$ & $0.68^{*}$ & $0.69^{*}$ & $0.68^{*}$ & $0.29^{*}$ & $0.28^{*}$ & $0.28^{*}$ \\
\hline & (5.13) & (5.28) & $(5.76)$ & $(14.51)$ & (14.63) & (14.43) & $(5.04)$ & (5.17) & $(5.62)$ \\
\hline$R^{2}$ & 0.80 & 0.80 & 0.81 & 0.93 & 0.93 & 0.94 & 0.78 & 0.78 & 0.79 \\
\hline Wald $x^{2}$ & $\begin{array}{c}411.39 \\
{[10]}\end{array}$ & $\begin{array}{c}470.54 \\
{[11]}\end{array}$ & $\begin{array}{c}460.32 \\
{[11]}\end{array}$ & $\begin{array}{c}333.72 \\
{[10]}\end{array}$ & $\begin{array}{c}337.06 \\
{[11]}\end{array}$ & $\begin{array}{c}345.61 \\
{[11]}\end{array}$ & $\begin{array}{c}393.29 \\
{[10]}\end{array}$ & $\begin{array}{c}455.49 \\
{[11]}\end{array}$ & $\begin{array}{c}450.25 \\
{[11]}\end{array}$ \\
\hline Obs. & 217 & 217 & 217 & 217 & 217 & 217 & 217 & 217 & 217 \\
\hline
\end{tabular}


Table 3. Effects of PIM and PSM trade on employment.

\begin{tabular}{|c|c|c|c|c|c|c|c|c|c|}
\hline \multirow{2}{*}{$\begin{array}{c}\text { Dependant Variable } \\
\text { Variable }\end{array}$} & \multicolumn{3}{|c|}{ Model 1 Total Employment } & \multicolumn{3}{|c|}{ Model 2 The Skilled Employment } & \multicolumn{3}{|c|}{ Model 3 The Unskilled Employment } \\
\hline & (1) & (2) & (3) & (1) & (2) & (3) & (1) & (2) & (3) \\
\hline \multirow[t]{2}{*}{ PIM export } & $0.77^{*}$ & & & $1.00^{*}$ & & & $0.81^{*}$ & & \\
\hline & $(5.09)$ & & & $(6.05)$ & & & (4.89) & & \\
\hline \multirow{2}{*}{ PSM export } & 0.00 & & & $1.44^{*}$ & & & -0.07 & & \\
\hline & $(-0.01)$ & & & $(3.63)$ & & & $(-0.25)$ & & \\
\hline \multirow[t]{2}{*}{ Net PIM export } & & $1.10^{*}$ & & & $1.51^{*}$ & & & $1.18^{*}$ & \\
\hline & & $(5.15)$ & & & $(5.86)$ & & & $(5.03)$ & \\
\hline \multirow[t]{2}{*}{ Net PSM export } & & -1.10 & & & 1.67 & & & -1.07 & \\
\hline & & $(-1.41)$ & & & $(1.43)$ & & & $(-1.35)$ & \\
\hline \multirow[t]{2}{*}{ PIM import } & & & 0.48 & & & $1.16^{*}$ & & & 0.51 \\
\hline & & & $(1.72)$ & & & $(3.59)$ & & & $(1.64)$ \\
\hline \multirow[t]{2}{*}{ PSM import } & & & 0.20 & & & $1.72^{*}$ & & & 0.12 \\
\hline & & & $(0.47)$ & & & $(2.85)$ & & & $(0.27)$ \\
\hline \multirow[t]{2}{*}{ Processing trade size } & 0.00 & 0.00 & 0.00 & 0.00 & 0.00 & 0.00 & 0.00 & 0.00 & 0.00 \\
\hline & $(0.1)$ & $(0.33)$ & $(0.19)$ & $(-0.5)$ & $(-0.11)$ & $(-0.18)$ & $(0.09)$ & $(0.31)$ & $(0.19)$ \\
\hline \multirow[t]{2}{*}{ Wage } & $-0.40^{*}$ & $-0.33^{*}$ & $-0.38^{*}$ & $-0.59^{*}$ & $-0.51^{*}$ & $-0.58^{*}$ & $-0.39^{*}$ & $-0.32^{*}$ & $-0.38^{*}$ \\
\hline & $(-5.88)$ & $(-4.87)$ & $(-5.18)$ & $(-6.52)$ & $(-5.16)$ & $(-6.06)$ & $(-5.52)$ & $(-4.61)$ & $(-4.87)$ \\
\hline \multirow[t]{2}{*}{ Other Output } & $0.29^{*}$ & $0.25^{*}$ & $0.20^{*}$ & $0.69^{*}$ & $0.70^{*}$ & $0.65^{*}$ & $0.29^{*}$ & $0.25^{*}$ & $0.20^{*}$ \\
\hline & $(5.31)$ & (5.53) & (3.7) & (14.79) & (14.58) & (13.05) & (5.19) & (5.39) & $(3.42)$ \\
\hline$R^{2}$ & 0.79 & 0.80 & 0.82 & 0.93 & 0.94 & 0.94 & 0.77 & 0.78 & 0.80 \\
\hline Wald $x^{2}(11)$ & 458.8 & 522.1 & 335.3 & 347.7 & 307.2 & 292.5 & 443.1 & 501.0 & 326.4 \\
\hline Obs. & 217 & 217 & 217 & 217 & 217 & 217 & 217 & 217 & 217 \\
\hline
\end{tabular}

Notes: Random-Effects Analysis is used. Time-specific effects are estimated. And the robust variance estimator is used to improve the overall estimate's smallsample properties. Z-Value in parentheses. The symbols *denotes significance at $1 \%$ levels.

aim, not export expansion. Thus PSM export is not a case for "vent for surplus" theory, and doesn't work on regional employment. Different from PSM, import from outside for PIM trade is for promotion export expansion. PIM export could apply to "vent for surplus" theory and increase labor demand.

In Table 3, both coefficients of PIM and PSM import are positive, statistically significant in Model 2, but insignificant in Model 1 and Model 3. This result further proves the import induced by processing trade, whatever by PIM or PSM, prompts regional demand for the skilled labor. Thus processing import is the root for skill-bias effect of processing trade on employment.

Additionally, the classic driving forces of labor demand-average wage turn out to have the expected negative and significant effect on regional employment as shown by Tables 2 and 3. The 1\% increase in wage leads to $0.40 \%$ increase in regional total employment. The real output excluding processing export also has the expected positive and significant effect on regional employment. The $1 \%$ increase of the real output leads to $0.28 \%$ increase in regional total employment.

\section{Conclusions}

This study investigates the role of processing trade plays in regional employment in China. The results give evidence that processing trade has a significant positive impact on labor employment. But the positive effect is more orientated toward the skilled labor. Hereinto, processing import, including PIM and PSM import, especially the capital goods import by processing trade, is the root of the skill-bias effect of processing trade on employment. 
Net processing export is a driving to expand employment, including the skilled and the unskilled, which is consistent with "vent for surplus" theory. But only PIM export it is, PSM export has no "vent for surplus" effect. For other classic factors, average wage and real output have strong expected effects on regional employment.

The study has important implications for government policies for increasing employment. On the one hand, local government could facilitate processing trade to stimulate local employment. On the other hand, processing trade has a skill-bias effect on employment and this may further lead to wage gaps between the skilled and the unskilled. Policies preference for PIM export, especially big net PIM export, could partly ease this problem. At the same time, the government needs to devote more resource to manpower investment to upgrade labor force.

\section{REFERENCES}

[1] R. C. Feenstra and G. H. Hanson, "Globalization, Outsourcing, and Wage Inequality," American Economic Review, Vol. 86, No. 2, 1996, pp. 240-245.

[2] L. S. Ho, X. D. Wei and W. C. Wong, "The Effect of Outward Processing Trade on Wage Inequality: The Hong Kong Case,” Journal of International Economics, Vol. 67, No. 1, 2005, pp. 241-257. doi:10.1016/j.jinteco.2004.09.005

[3] M. S. Leclair, "Export Composition and Manufacturing Employment in the US during the Economic Downturn of 1991-92," Economic Systems Research, Vol. 14, No. 2, 2002, pp. 147-156. doi:10.1080/09535310220140942

[4] P. Ruiz-Nápoles, "Exports, Growth, and Employment in Mexico, 1978-2000,” Journal of Post Keynesian Economics Vol. 27, No. 1, 2004, pp. 105-124.

[5] X. Fu and V. N. Balasubramanyam, "Export, Foreign Direct Investment and Employment: The Case of China,”
World Economy, Vol. 28, No. 4, 2005, pp. 607-625. doi:10.1111/j.1467-9701.2005.00694.X

[6] R. C. Feenstra and C. Hong, "China’s Exports and Employment,” In: China's Growing Role in World Trade, NBER Working Paper No. 13552, Cambridge, 2010, pp. 167-199.

[7] R. M. Leichenko and N. E. Coulson, "Foreign Industrial Exports and State Manufacturing Performance," Growth and Change Vol. 30, No. 4, 1999, pp. 479-506. doi:10.1111/j.1468-2257.1999.tb00042.x

[8] R. M. Leichenko, "Exports, Employment, and Production: a Causal Assessment of U.S. States and Regions," Economic Geography, Vol. 76, No. 4, 2000, pp. 303-325. doi:10.2307/144389

[9] R. Koopman, Z. Wang and S. J. Wei, "How Much of Chinese Exports Is Really Made in China? Assessing Domestic Value-Added When Processing Trade Is Pervasive,” NBER Working Paper 14109, Cambridge, 2008.

[10] A. Conte and M. Vivarelli, "Globalization and Employment: Imported Skill Biased Technological Change in Developing Countries,” Jena Economic Research Papers 2007-009, Jena, 2007.

[11] A. Mitra, “Technology Import and Industrial Employment: Evidence from Developing Countries," Labour, Vol. 23, No. 4, 2009, pp. 697-718. doi:10.1111/j.1467-9914.2009.00461.x

[12] X. Fu and V. N. Balasubramanyam, "Township and Village Enterprises in China,” Journal of Development Studies Vol.39, No. 4, 2003, pp. 37-46. doi:10.1080/713869424

[13] S. Y. Tong and Y. Zheng, "China's Trade Acceleration and the Deepening of an East Asian Regional Production Network," China and World Economy, Vol. 16, No. 1, 2008, pp. 66-81. doi:10.1111/j.1749-124X.2008.00100.X

[14] S. Lall and M. Albaladejo, "China's Competitive Performance: A Threat to East Asian Manufactured Exports?" World Development, Vol. 32, No. 9, 2004, pp. 1441-1466. 